\title{
EHMTI-0250. General practitioners' experiences with brief intervention for medication-overuse headache: a qualitative study
}

\author{
ES Kristoffersen ${ }^{1 *}$, C Lundqvist $^{2}$, JC Frich $^{3}$ \\ From 4th European Headache and Migraine Trust International Congress: EHMTIC 2014 \\ Copenhagen, Denmark. 18-21 September 2014
}

\section{Introduction}

Medication-overuse headache $(\mathrm{MOH})$ is common in the general population, and the majority of sufferers are managed in primary health care. Brief Intervention (BI) has been used as a motivational technique for patients with drug and alcohol overuse, and may a have role in the treatment of $\mathrm{MOH}$.

\section{Aim}

To explore GPs' experiences using BI in the management of patients with $\mathrm{MOH}$.

\section{Method}

Qualitative study in Norwegian general practice. Data was collected through four focus group interviews with 22 GPs who participated in an intervention study on $\mathrm{BI}$ for $\mathrm{MOH}$. We used systematic text condensation to analyse transcripts from the focus group interviews.

\section{Results}

The GPs experienced challenges when trying to convince patients that the medication they used to treat and prevent headache could cause headache, but labelling $\mathrm{MOH}$ as a diagnosis opened up space for action. GPs were able to use BI within the scope of a regular consultation, and they thought that the structured approach had a potential to change patients' views about their condition and medication use. Being diagnosed with medication overuse could bring about feelings of guilt in patients, and GPs emphasised that a good alliance with the patient was necessary for successful change using $\mathrm{BI}$ to manage $\mathrm{MOH}$.

\section{Conclusion}

GPs experience BI as a feasible strategy to treat $\mathrm{MOH}$, and the technique relies on a good alliance between the doctor and patient. When using BI, GPs must be prepared to counter patients' misconceptions about medication used for headache.

No conflict of interest.

\section{Authors' details}

${ }^{1}$ Department of General Practice, University of Oslo, Oslo, Norway. ${ }^{2}$ Research Centre, Akershus University Hospital, Lørenskog, Norway. ${ }^{3}$ Institute of Health and Society, University of Oslo, Oslo, Norway.

Published: 18 September 2014

doi:10.1186/1129-2377-15-S1-C32

Cite this article as: Kristoffersen et al.: EHMTI-0250. General practitioners' experiences with brief intervention for medication-overuse headache: a qualitative study. The Journal of Headache and Pain 2014 15(Suppl 1):C32.

Submit your manuscript to a SpringerOpen ${ }^{\odot}$ journal and benefit from:

- Convenient online submission

- Rigorous peer review

- Immediate publication on acceptance

- Open access: articles freely available online

- High visibility within the field

- Retaining the copyright to your article

Submit your next manuscript at $>$ springeropen.com

\section{SpringerOpen ${ }^{\circ}$}

(c) 2014 Kristoffersen et al; licensee Springer. This is an Open Access article distributed under the terms of the Creative Commons Attribution License (http://creativecommons.org/licenses/by/2.0), which permits unrestricted use, distribution, and reproduction in any medium, provided the original work is properly cited. 